\title{
Silver paints in medieval manuscripts: a first molecular survey into their degradation
}

\author{
Rita Araújo ${ }^{1,2}$ (D, Paula Nabais ${ }^{1,2}$, Isabel Pombo Cardoso ${ }^{1}$, Conceição Casanova ${ }^{1,2}$, Ana Lemos²
}

and Maria J. Melo $0^{1,2^{*}}$

\begin{abstract}
The lack of comprehensive studies on silver paints in manuscripts is a handicap to new stabilization strategies and treatments. This work develops and tests a methodological approach for the study of the degradation of silver paints, at the molecular level, using as a case study a French Book of Hours dated from the 15th century from Mafra National Palace collection. In this paper, we show that the global equation commonly used by the cultural heritage community to describe the tarnishing of silver proves to be insufficient to understand the main factor causing its severe and extensive darkening in medieval illuminated manuscripts. This equation depicts the degradation of silver instantly with a sulphide containing species as $\mathrm{H}_{2} \mathrm{~S}$. Recent research has solidly proved that the first intermediate of silver oxidation is $\mathrm{Ag}_{2} \mathrm{O}$. This theme will be presented in a forthcoming review. Within this framework, we selected four typologies of silver paints, all analysed by in situ techniques and four as microsamples; due to the very small size and fragility of the microsamples, new methods of sample preparation were developed and tested. The main research questions include: (1) understanding how silver-based colour are formed, disclosing its full stratigraphy; (2) define if the other compounds present, such as colour paints and the ground, may affect silver oxidation by stabilizing or accelerating it; (3) comprehend if it is possible to characterize the degradation products of silver paints with the methodology developed in this work, both in the bulk and at the interfaces between layers. Overall our results show that silver-based colours exhibit a complex stratigraphy that impacts its conservation condition. Further research at the molecular level is required on the correlation of the main components of the ground (binder and filler such as gypsum and calcium carbonate) and the paints that are applied as layers over or under the silver leaf. Our case studies have shown that both in situ analytical techniques and scanning electron microscopy with energy dispersive spectroscopy analysis in the microsamples, provide relevant information on the silver colour stratigraphy. However, the information obtained studying cross-sections is more accurate. We consider that the study of the degradation mechanism of silver in medieval illuminated manuscripts will require the combination of both approaches; in situ methodologies support the relevance of the data acquired on the microsamples. Microsamples studies will make possible the acquisition of data that is fundamental to understand the darkening of silver paints and this, in turn, is essential to develop informed and sustainable conservation policies.
\end{abstract}

Keywords: Silver leaf, Medieval paintings, Silver sulphide, Book of hours, Preservation, Conservation

\section{Introduction}

Over the past decade, an interdisciplinary research on medieval books in Portuguese collections held at public institutions has been carried out [1]. A recent

\footnotetext{
*Correspondence: mjm@fct.unl.pt

${ }^{1}$ DCR and LAQV-REQUIMTE, Faculty of Sciences and Technology, Universidade NOVA de Lisboa, Campus da Caparica, 2829-516 Caparica, Portugal

Full list of author information is available at the end of the article
}

investigation, on the systematic study of the colour materials applied in the illumination of the books of hours preserved in Portuguese institutions, showed that silver is lavishly applied in backgrounds, highlights and minute details [2-12]. In most of the cases, silver colours present dramatic blackening, but in some manuscripts, the metal brightness is still present. Although the application of silver leaf in illuminated manuscripts has been referred by several authors [13-25], the study of silver degradation 
in the cultural heritage field has been mainly associated with metal artefacts, jewellery or composite objects such as altarpieces, polychrome and gilded objects, silver threads in textile, daguerreotype photos and silverpoint drawings [26-38]. Despite its importance for cultural heritage preservation, there is little consensus on the literature regarding silver degradation mechanisms. Investigation of the molecular processes of silver oxidation show that the direct pathway, Eq. 1, that has been proposed and accepted by the cultural heritage field for silver tarnishing, does not depict the essential mechanism; in fact, silver, pure or in an alloy, does not react directly with sulphide forming silver sulphide $\left(\mathrm{Ag}_{2} \mathrm{~S}\right)$, even in the presence of high sulphide concentrations [26, 39]. According to Besenbacher and Nørskov, as cited by Homem [39-41], the first step of the overall oxidation process initiates with the adsorption of oxygen on the surface of silver. Leygraf and Graedel [42] demonstrated that when in the presence of humidity, the oxidized surface will react with the water from the atmosphere, forming hydroxyl compounds and a thin layer of water. According to these authors [39, 42], in a museum environment, only $2-5 \%$ of $\mathrm{RH}$ is necessary to form an oxide and $15 \% \mathrm{RH}$ to form a monolayer of water over the oxidized surface. In addition,

Table 1 The first oxidation product is $\mathrm{Ag}_{2} \mathrm{O}$ that by ligand substitution is converted into $\mathrm{Ag}_{2} \mathrm{~S}$

\begin{tabular}{llc}
\hline & $\mathbf{E}^{\circ} / \mathbf{V}$ & $\boldsymbol{\Delta} \mathbf{G}^{\circ} / \mathbf{k J} / \mathbf{m o l}$ \\
\hline $\mathrm{O}_{2}(\mathrm{~g})+4 \mathrm{Ag}(\mathrm{s}) \rightarrow 2 \mathrm{Ag}_{2} \mathrm{O}(\mathrm{s})$ & 0.43 & -22.42 \\
$\mathrm{Ag}_{2} \mathrm{O}(\mathrm{s})+\mathrm{H}_{2} \mathrm{~S}(\mathrm{~g}) \rightarrow \mathrm{Ag}_{2} \mathrm{~S}(\mathrm{~s})+\mathrm{H}_{2} \mathrm{O}(\mathrm{aq})$ & - & -233.26 \\
$\mathrm{Ag}_{2} \mathrm{O}(\mathrm{s})+\mathrm{COS}(\mathrm{g}) \rightarrow \mathrm{Ag}_{2} \mathrm{~S}(\mathrm{~s})+\mathrm{CO}_{2}(\mathrm{~g})$ & - & -256.94 \\
\hline
\end{tabular}

$\Delta \mathrm{G}^{\circ}$ value calculated with reference data from [43] we propose that the biradicaloid nature of oxygen is the driving force for the first electron transfer from silver to oxygen, forming intermediates of the type $\mathrm{O}_{2}^{2-}$. The complete transfer of $4 \mathrm{e}^{-}$enables the formation of two $\mathrm{O}^{2-}$ and consequently of $\mathrm{Ag}_{2} \mathrm{O}$. It is through this intermediate, $\mathrm{Ag}_{2} \mathrm{O}$, that $\mathrm{Ag}_{2} \mathrm{~S}$ is formed, since oxygen is replaced by $\mathrm{S}^{2-}$, when available, due to the higher $K_{s p}$ of the for$\operatorname{mer}\left(K_{s p} \mathrm{Ag}_{2} \mathrm{O}=2.6 \times 10^{-8}, K_{s p} \mathrm{Ag}_{2} \mathrm{~S}=6.0 \times 10^{-50}\right)$ [42], Table 1. Likewise, for the formation of silver chlorides, sulphates, and hydroxides. In the case of a chloride ion and/or radical, the possibility of a direct reaction must also be considered. A full mechanisms of silver corrosion will be presented and explained in a micro review that is in progress.

$$
2 \mathrm{Ag}(\mathrm{s})+\mathrm{H}_{2} \mathrm{~S}(\mathrm{~g}) \rightarrow \mathrm{Ag}_{2} \mathrm{~S}(\mathrm{~s})+\mathrm{H}_{2}(\mathrm{~g})
$$

In medieval ages, silver has been applied in illuminations, as leaf or powder, and could be found in skies, lakes, windows, floors and quotidian objects depicted in the illumination, Fig. 1. In decorated borders, silver was used in animals, flowers and vessels, or could even be used as a writing ink. Gilding techniques, concerning gold and silver, have been referred in many medieval recipes and treatises [44-51]. The metallic leaves could be applied over the parchment surface, previously burnished, or over a ground layer. In the cases that we analysed, the grounds were prepared with gypsum, calcium carbonate or a mixture of both, combined with proteinaceous or polysaccharide binders [4, 52]. Yellow ochres and vermilion could be applied over the ground as a bolus layer [52]. Finally, the metallic leaves are applied and burnished. Following that, pigments could be applied over the metallic surface to construct minute details or to shade it, Figs. 2 and 3.
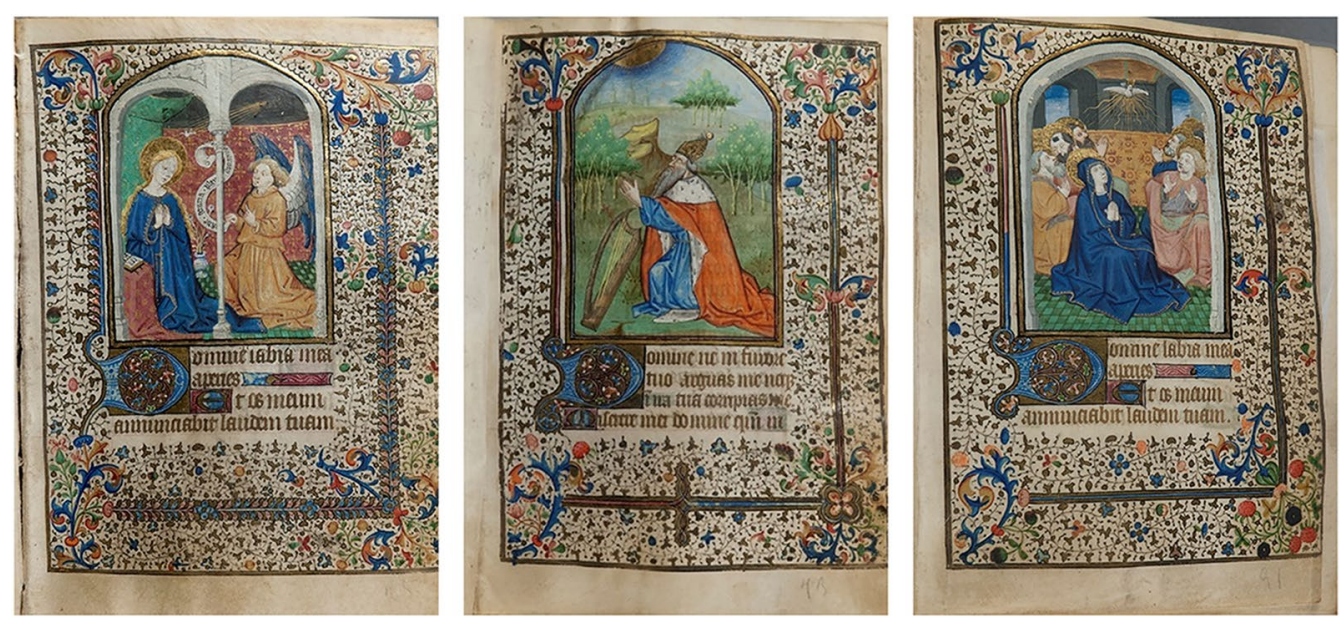

Fig. 1 Book of Hours Cofre no31 (Paris, ca. 1440-1490), folios 25, 73 and 91 (PNM) 




Fig. 2 Schematic reconstruction of a stratigraphy of a silver sky background: over the parchment, a ground is applied that is the base for silver; on top of it, lapis lazuli is used to draw the clouds; indigo is used to shade the metal leaf. This proposal is based on the analysis of Ms Cofre no24 [4, 11]

The lack of comprehensive studies on silver paints in manuscripts is an obstacle to new stabilization strategies and treatments. This work develops and tests a methodological approach for the study of the degradation of silver paints, at the molecular level, using as a case study a French Book of Hours, cofre no31, dated from the 15th century and belonging to the Mafra National Palace collection (PNM), Fig. 1. To understand our research questions, it is important to bear in mind that in many cases the silver paint is so severely degraded that information regarding the forms and colours is lost; with the naked eye, what we see is a black form with fuzzy contours, Fig. 3. Research questions include: (1) understand the transformation of silver and its impact on the other colours that are in contact with it; (2) find out if the other colour paints and the ground may affect silver oxidation, by stabilization or accelerating it; (3) comprehend if it is possible to characterize the degradation products of silver paints, both in the bulk and at the interfaces of the different layers of colour.

Elemental and molecular characterization of the colour palette of Ms Cofre no31 was carried out by energy dispersive X-ray fluorescence ( $\mu$-EDXRF), Raman microscopy ( $\mu$-Raman), $\mu$-Fourier transform infrared spectroscopy ( $\mu$-FTIR) and fiber optic reflectance spectroscopy (FORS) in the framework of a previous study [12]; organic chromophores were confirmed using microspectrofluorimetry in the UV-Vis for the present study. Overall, the colourants found in the original corpus, dated from ca. 1440 , are: azurite $\left(2 \mathrm{CuCO}_{3} \cdot \mathrm{Cu}(\mathrm{OH})_{2}\right)$, lapis lazuli $\left(\mathrm{Na}_{8}\left[\mathrm{Al}_{6} \mathrm{SiO}_{24}\right] \mathrm{S}_{\mathrm{n}}\right)$, sometimes over the azurite, and indigo for the blues; vermilion ( $\mathrm{HgS})$, it is minium, the name of a medieval pigment $\left(\mathrm{Pb}_{3} \mathrm{O}_{4}\right)$ and brazilwood lake for painting the reds; the yellow colours are obtained with lead-tin yellow type $\mathrm{I}\left(\mathrm{Pb}_{2} \mathrm{SnO}_{4}\right)$ and mosaic gold $\left(\mathrm{SnS}_{2}\right)$; malachite $\left(\mathrm{CuCO}_{3} \cdot \mathrm{Cu}(\mathrm{OH})_{2}\right)$ was used for the green colours and, sometimes, an organic pigment was applied to shade it; highlights are applied with lead white $\left(2 \mathrm{PbCO}_{3} \cdot \mathrm{Pb}(\mathrm{OH})_{2}\right)$ and carbon black $(\mathrm{C})$ was used for the black tones; silver (Ag) was applied as leaf and gold $(\mathrm{Au})$ as leaf or powder.

In situ techniques were not effective in acquiring information regarding the silver paints stratigraphy; to overcome this obstacle, scanning electron microscopy with energy dispersive spectroscopy (SEM-EDS) was tested in the microsamples. Different sample preparation methods were designed and their efficacy compared; the proportion of calcium carbonate $\left(\mathrm{CaCO}_{3}\right)$ and gypsum $\left(\mathrm{CaSO}_{4} \cdot 2 \mathrm{H}_{2} \mathrm{O}\right)$, applied on the grounds of the silver leaves, was also addressed. The results obtained enabled us to characterize both the silver leaf and ground layers, as well as degradation products, contributing to a better understanding of the corrosion mechanisms of silver paints in medieval manuscripts.

\section{Methods/experimental \\ Book of hours}

The manuscript cofre no31, from the books of hours collection, is preserved in the Library of Mafra National Palace (PNM) and has been kept in a safe at the historical library. Dated from ca. 1440-1490 (origin: France, Paris), the manuscript measures $180 \times 131 \times 68 \mathrm{~mm}$. It consists of 162 folios (ff.) of parchment with 15 lines of text, written in Latin and French, and 3 illuminations with 4 lines of text underneath. Some of the borders are decorated with golden ivy leaves, flowers, acanthus leaves and strawberries. The bookbinding of this book was added later, between late 18th century-early 19th century, in Portugal, following the binding style of the 18th century library of Mafra National Palace, using identical decoration and materials. 

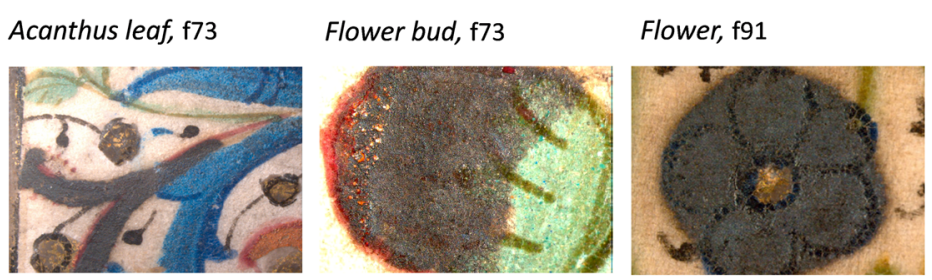

Window, f25
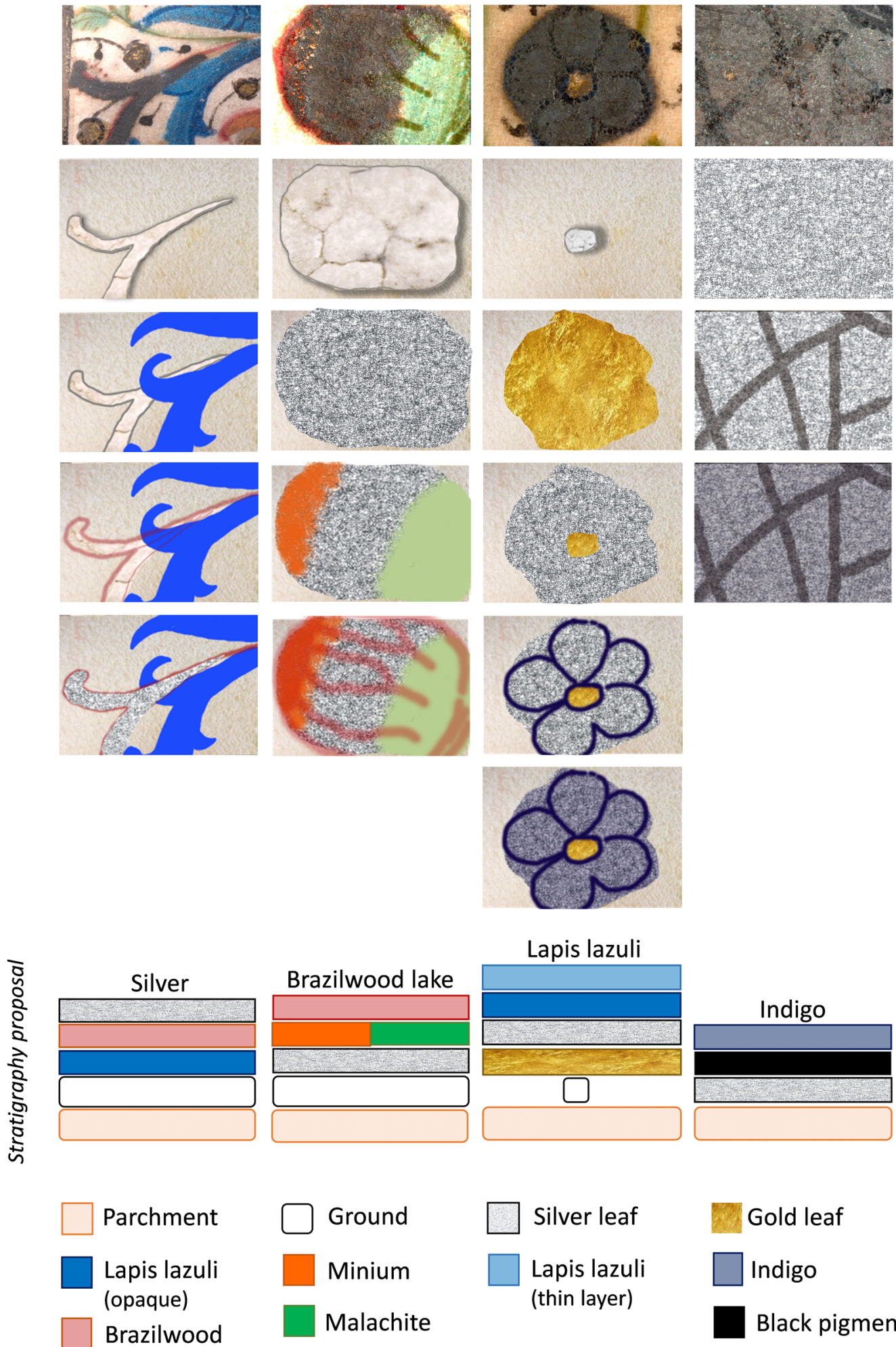

Silver leaf

Gold leaf

Lapis lazuli (thin layer)

Fig. 3 Step by step reconstruction and proposals for the stratigraphies of the different applications of silver paints found in Ms Cofre no31, (Paris, ca. 1440-1490) 


\section{Analytical techniques}

A total of seven folios were studied previously $(25,62,73$, 91, 147v, 153 and 160) [12] and in this project three were addressed: 25, 73 and 91. Usually, per folio, each colour was analysed in two to three different areas (collecting per area in two to three points), to ensure relevance. Micro-sampling in representative areas was performed using a microchisel from Ted Pella under a Leica MZ16 stereomicroscope $(7.1 \times$ to $115 \times$ zoom range), equipped with a Leica ICD digital camera and a fibreoptic light Leica system (Leica KI 1500 LCD). Here, seven microsamples, measuring circa $100 \mu \mathrm{m}$ were taken from folio 73 (cofre no 31), and photos from the sampled areas were recorded. The microsamples were analysed by complementary analytical techniques:

X-ray fluorescence data was obtained with an ArtTAX spectrometer of Intax $\mathrm{GmbH}$, with a molybdenum (Mo) anode, a Peltier cooled SDD (silicon drift detector), model Xflash, installed in a mobile arm of the spectrometer, was used to collect the produced X-rays. The use of pollycapillary lens allows beam spot analysis with a spatial resolution of $70 \mu \mathrm{m}$. The experimental parameters used were: $40 \mathrm{kV}$ of voltage, $300 \mu \mathrm{A}$ of current intensity, and $150 \mathrm{~s}$ of acquisition time. A poly(methyl methacrylate) (PMMA) sheet was inserted under each folio studied, and the areas of analysis were carefully chosen so that no paint was on the other side.

Raman microscopy was carried out using a Labram 300 Jobin-Yvon spectrometer, equipped with a $\mathrm{He}-\mathrm{Ne}$ laser of $17 \mathrm{~mW}$ power operating at $632.8 \mathrm{~nm}$ and a solid state laser operating at $532 \mathrm{~nm}$. Spectra were recorded as an extended scan. The laser beam was focused with a $50 \times$ or $100 \times$ Olympus objective. The laser power at the surface of the samples was varied with the aid of a set of neutral density filters (optical densities $0.3,0.6,1$ ).

Infrared spectra were acquired with a Nicolet Nexus spectrophotometer coupled to a Nicolet Continupm microscope $(15 \times$ objective) with a mercury-cadmiumtelluride (MCT) detector cooled by liquid nitrogen. Spectra were obtained in transmission mode, between $4000-650 \mathrm{~cm}^{-1}$, resolution of $4 \mathrm{~cm}^{-1}$, and 128 or 256 scans. Microsamples were previously compressed using a Thermo diamond anvil compression cell. Spectra are shown here as acquired, without corrections or any further manipulations, except for the occasional removal of the $\mathrm{CO}_{2}$ absorption at ca. $2300-2400 \mathrm{~cm}^{-1}$. For the ground references, FTIR analyses were performed on the same Nicolet Nexus spectrophotometer using $\mathrm{KBr}$ pellets. The spectra were collected in transmission mode, between $4000-400 \mathrm{~cm}^{-1}$, with a resolution of $4 \mathrm{~cm}^{-1}$ and 64 scans.
Fluorescence excitation and emission spectra were recorded on a Jobin-Yvon/Horiba SPEX Fluorog 3-2.2 spectrofluorimeter. Fluorescence spectra were corrected for the wavelength response of the system. For spectrofluorimetry analyses, the latter equipment was hyphened to an Olympus BX51M confocal microscope, with spatial resolution controlled with a multiple-pinhole turret, corresponding to a minimum $2 \mu \mathrm{m}$ and maximum $60 \mu \mathrm{m}$ spot, with $50 \times$ objective. Emission spectra were acquired exciting at $490 \mathrm{~nm}$, and excitation spectra were performed collecting the signal at 610 or $620 \mathrm{~nm}$. Both were acquired in a $30 \mu \mathrm{m}$ spot (pinhole 8 ) and the following slits set: emission slits $=3 / 3 / 3 \mathrm{~mm}$, and excitation slits $=5 / 3 / 0.8 \mathrm{~mm}$. The optimization of the signal, through mirror alignment in the optic pathway of the microscope, was performed for all pinhole apertures following the manufacturer instructions. Spectra were collected after focusing the microsample followed by signal intensity optimization (detector reading). Emission and excitation spectra were acquired in the same spot whenever possible.

SEM images were obtained using a FEI Quanta 400 FEG ESEM, which uses a Schottky field emission gun, operating at low vacuum conditions and at $15 \mathrm{kV}$, equipped with an EDAX Genesis X4M detector. Images were acquired using backscattered electron detector (BSED). SEM was performed within the Portuguese microscopy network RENM, at CEMUP-Centro de Materiais, Universidade do Porto.

\section{References preparation}

References were prepared with chalk $\left(\mathrm{CaCO}_{3}\right)$, from Roig Farma, gypsum $\left(\mathrm{CaSO}_{4} \cdot 2 \mathrm{H}_{2} \mathrm{O}\right)$, from Panreac, collagen, from "Jerónimos" gelatin, $\mathrm{KBr}$ and distilled water. Firstly, chalk and gypsum were ground together in a mortar with different ratios, from 90:10 to 10:90. Following that, the different combinations were prepared as collagen paint and as a pellet. The ground paints references were made by admixing the mixtures of compounds $(0.1 \mathrm{~g})$ with collagen binder $(0.05 \mathrm{ml})$, and applied over glass slides. The microsamples were compressed in a diamond cell for infrared analysis. The binder was prepared in a first stage, leaving the gelatine leaf in water for $2 \mathrm{~h}$, and then was subjected to $90{ }^{\circ} \mathrm{C}$ with stirring. Concerning the pellets, the mixtures of compounds $(0.1 \mathrm{~g})$ were ground with $\mathrm{KBr}$ powder $(0.1 \mathrm{~g})$, and pressed under high pressure (10 tons, during $10 \mathrm{~min})$. For both methods and different components proportion, three replicates were prepared and analysed.

Brazilwood reference samples were prepared following the recipes 9 and 27 from The book how to make colours. For more details, see [53]. 


\section{Results and discussion}

Our aim is to study silver paints with different degrees of degradation. This study involved the analyses of silver paint areas that were produced using different techniques, namely: silver leaf over a ground (folio 73, analysed in situ and in microsamples) and silver leaf applied directly on parchment support (folio 25 and 91, analysed only in situ).

The areas studied and sampled on folio 73 included the blue acanthus leaf, microsamples A1 and A2; a green leaf, microsamples $\mathrm{C} 1, \mathrm{C} 2$ and $\mathrm{C} 3$; and, the red flower bud, microsamples B1 and B2, Table 2.

The areas analysed on folio 91, blue flower, and folio 25 , window, showed differences in the degree of degradation, being less extensive in the case of folio 25, Fig. 3 and Table 2.

\section{Microsamples preparation}

The seven microsamples from the silver paint areas of the folio 73 , with circa $100 \mu \mathrm{m}$ in diameter, were collected with the help of a microchisel and a tungsten needle, under a Leica KL 1500 LCD microscope.

Three different sample preparation methods were designed to enable the analysis of the fragile and degraded stratigraphies by SEM-EDS, Table 2.

We tested the possibility of two different tapes to hold in an upright position the microsamples: a carbon conductive tape (sample A1 and A2); and a polypropylene tape with poly(2-ethylhexyl acrylate) adhesive (TF500 Fluxana ${ }^{\circledR}$ ) (microsample B1 and B2). This method did not ensure the correct stratigraphic positioning of the microsamples, being difficult to guarantee that only the desired layer is excited.

The second method tested included the mounting of three microsamples between two films of polypropylene (Ultralene $\left.{ }^{\circledR}\right)$, which were glued to an opening of an eppendorf tube (microsamples C1, C2 and C3). Although commonly used for synchrotron analysis, this method showed to be unsuccessful under SEM-EDS, since the material totally absorbs the excitation beam.

The third method tested was the embedment of a microsample cross-section in acrylic resin (micro sample A1 that was removed from the carbon tape). The microsample laid on a glass slide was embedded in a drop of acrylic resin, Technovit ${ }^{\circledR} 2000 \mathrm{LC}$, and polymerized with blue light for $3 \mathrm{~min}$. After cured, the sample was fixed with Technovit ${ }^{\circledR} 2000$ LC fixing paste within a Teflon mounting mould with the stratigraphy facing upwards. The mould was filled with more acrylic resin which cured for $15 \mathrm{~min}$. Finally, the cross-section was revealed by dry polishing with micromesh ${ }^{\circledR}$ abrasive cloths (granulometry 600 and 8000). This method enabled the multilayer analysis of the microsample. The composition of the micromesh ${ }^{\circledR} 8000$ grit (aluminium oxide) was taken into account when interpreting the analytical results.

\section{Analysis by SEM-EDS of the silver paint in the blue acanthus leaf and its stratigraphy}

The colour studied in cross-section by SEM-EDS (microsample A1) was used in a blue vegetable decoration at the margin of the folio 73, on an acanthus leaf, over which silver was applied; the vegetable leaf was outlined with a pink lake, Fig. 3. It is important to note that, this is the only case study in which silver is applied over the pigments; in the other cases, colours are applied over silver. In Fig. $4 \mathrm{a}-\mathrm{c}$ and Table 3, we summarize the main results obtained by SEM-EDS analyses, which were confirmed by molecular spectroscopies, Fig. $5 \mathrm{a}-\mathrm{d}$. In summary, four layers were detected: over a gypsum based ground, an azurite paint was applied; in this microsample, the brazilwood lake outline is found over the azurite layer and, on top of both, azurite and pigment lake, a very thin silver leaf was applied.

Table 2 Analytical techniques used in the study of the silver paints found in Ms cofre no31

\begin{tabular}{|c|c|c|c|c|c|c|c|c|}
\hline & Analysed area & $\mu$-EDXRF & $\mu$-Raman & $\mu-F T I R$ & $\begin{array}{l}\text { SEM-EDS (carbon } \\
\text { tape) }\end{array}$ & $\begin{array}{l}\text { SEM-EDS (TF500 } \\
\text { Fluxana }{ }^{\circledR} \text { ) }\end{array}$ & $\begin{array}{l}\text { SEM-EDS (cross- } \\
\text { section) }\end{array}$ & $\begin{array}{l}\text { SEM-EDS } \\
\left(\text { Ultralene }{ }^{\circledR}\right)^{\mathrm{a}}\end{array}$ \\
\hline f. 25 & Window & $x$ & $x$ & - & - & - & - & - \\
\hline \multirow[t]{7}{*}{ f.73 } & \multirow[t]{2}{*}{ Blue acanthus leaf } & $x$ & $x$ & - & A1 & - & $\mathrm{A} 1$ & - \\
\hline & & $x$ & $x$ & - & $\mathrm{A} 2$ & - & - & - \\
\hline & \multirow[t]{3}{*}{ Green leaf } & - & - & - & - & - & - & $\mathrm{C} 1$ \\
\hline & & - & - & - & - & - & - & $\mathrm{C} 2$ \\
\hline & & - & - & - & - & - & - & $\mathrm{C} 3$ \\
\hline & \multirow[t]{2}{*}{ Red flower bud } & $x$ & $x$ & $x$ & - & B1 & - & - \\
\hline & & $x$ & $x$ & $x$ & - & B2 & - & - \\
\hline$f .91$ & Blue flower & $x$ & $x$ & - & - & - & - & - \\
\hline
\end{tabular}

a Not conclusive 

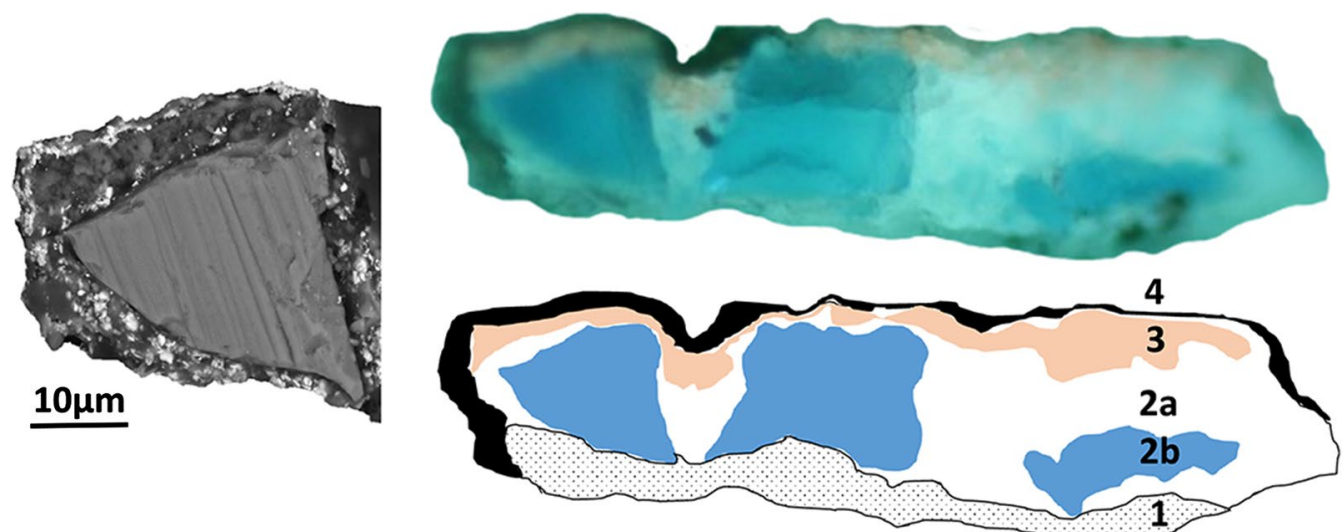

Fig. 4 (left) SEM and (top right) microscope images of the microsample from the blue acanthus leaf (bottom right). Schematic depiction of its stratigraphy: layer 1 (gypsum ground); layer 2: calcium carbonate as filler (2a) is admixed with azurite (2b) for the blue colour; layer 3 brazilwood lake outline; layer 4 silver leaf

Table 3 Summary of the results of the stratigraphy of microsample A1 based on SEM-EDS and molecular spectroscopies, for more details please see text

\begin{tabular}{|c|c|c|c|c|}
\hline A1 & $\begin{array}{l}\text { Layer } 1 \\
\text { Ground }\end{array}$ & $\begin{array}{l}\text { Layer } 2 \\
\text { Blue colour (filler and azurite) }\end{array}$ & $\begin{array}{l}\text { Layer } 3 \\
\text { Pink colour }\end{array}$ & $\begin{array}{l}\text { Layer } 4 \\
\text { Silver }\end{array}$ \\
\hline SEM image & & & & \\
\hline EDS results* & $\begin{array}{l}\mathrm{Ca}, \mathrm{S} \text { (gypsum) } \\
\mathrm{Pb} \text { (lead white) } \\
\mathrm{Ag} \text { (silver leaf) }\end{array}$ & $\begin{array}{l}\text { Ca (Chalk) } \\
\text { Cu (azurite) }\end{array}$ & $\begin{array}{l}\text { Ca, K, S (pink pigment lake) } \\
\text { Al, Si (lapis lazuli) } \\
\text { Ag (silver leaf) } \\
\text { Cu (azurite) } \\
\text { Pb (lead white) }\end{array}$ & $\mathrm{Ag}, \mathrm{S}\left(\mathrm{Ag}_{2} \mathrm{~S}\right)$ \\
\hline
\end{tabular}

* Elements $C$ and $O$ are always present in EDS spectra

SEM-EDS analysis seem to indicate that the first layer, the ground, is mainly composed of gypsum matrix $\left(\mathrm{CaSO}_{4} \cdot 2 \mathrm{H}_{2} \mathrm{O}\right)$; and of dispersed lead white $\left(2 \mathrm{PbCO}_{3} \cdot \mathrm{Pb}(\mathrm{OH})_{2}\right)$ hexagonal particles, arranged in lamellar form, Table 3. We could not disclose if the lead white was admixed to the ground or if it was used as an underdrawing, like an imprimitura of the ground.

Over this first layer, a blue colour is applied composed of particles circa $4 \mu \mathrm{m}$ in size with rough appearance and rounded shape; around these, crystals circa $20 \mu \mathrm{m}$ in size with a smooth surface are present; we propose that the smaller particles are calcium carbonate $\left(\mathrm{CaCO}_{3}\right)$, being the smoothed crystals copper carbonate $\left(2 \mathrm{CuCO}_{3} \cdot \mathrm{Cu}(\mathrm{OH})_{2}\right)$; although we cannot exclude the presence of copper oxide $(\mathrm{CuO})$. Associated with these copper based compounds, SEM-EDS shows a very thin layer with the presence of aluminium and silicium, which we propose to be a thin layer of lapis lazuli $\left(\mathrm{Na}_{8}\left[\mathrm{Al}_{6} \mathrm{Si}_{6} \mathrm{O}_{24}\right] \mathrm{S}_{\mathrm{n}}\right)$ applied over azurite. This assumption was confirmed by the molecular characterization of this layer performed with Raman microscopy. Based on the analysis made in illuminations from this book of hours [12], we verified that the lapis lazuli was applied over azurite in vestments of important figures, like the robe of the Virgin (f. 25), in the sky and vestment of King David (f. 73) and decorated elements, such as flowers and 

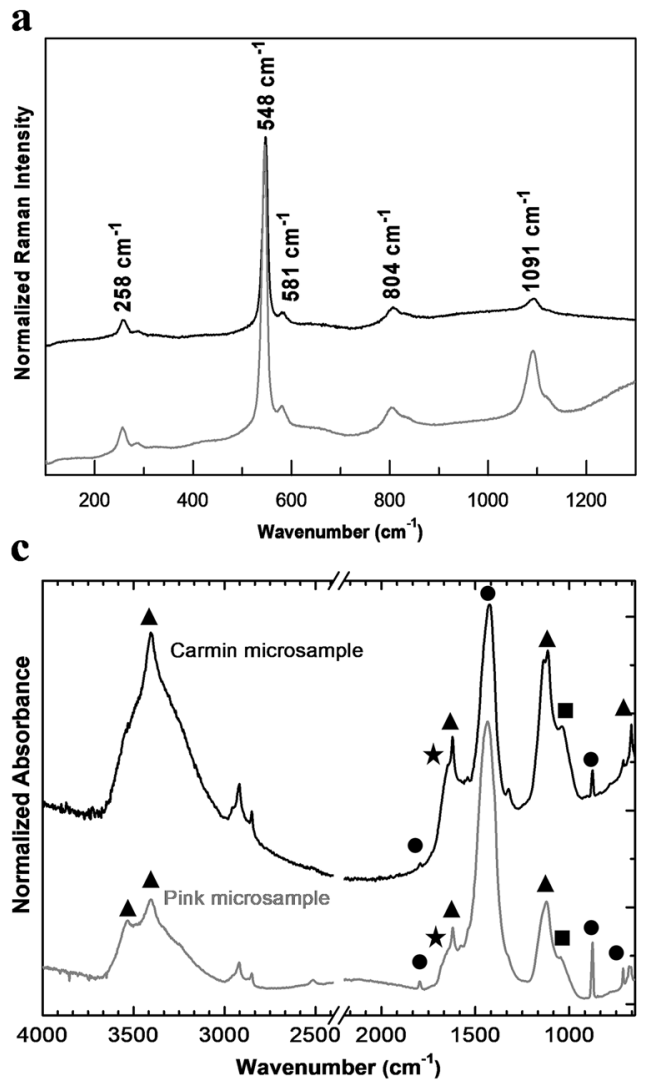

b



d

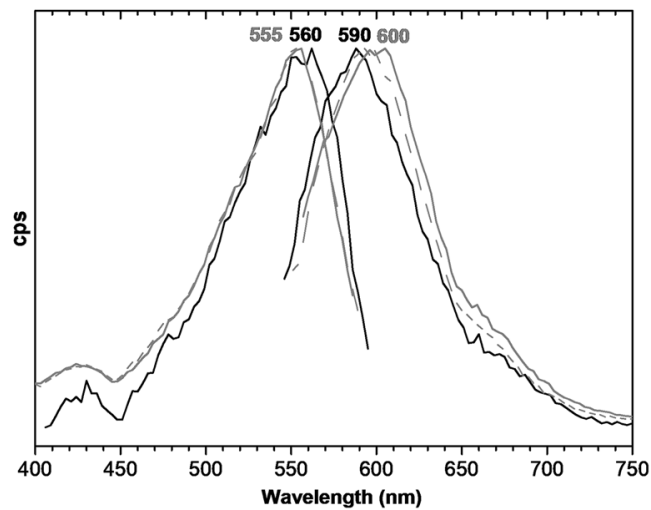

Fig. 5 Molecular identification of the blue acanthus leaf. The blue colour is obtained layering lapis lazuli (a) over azurite (b). The pink outline (c) is made with chalk (filled circle), gypsum (filled triangle), protein (filled star) and polysaccharide binder (filled square). The emission and excitation spectra (d) (black line) matches those of recipes 9 and 27 for brazilwood lake pigment from The book how to make colours (gray and dashed lines) [53]

leaves (ff. 25, 73 and 91) (Fig. 5a). In turn, other decorations as initials, flowers, line fillers and clothes of minor figures were only obtained with the application of azurite, Fig. 5b. This blue colour construction was also observed in other books of hours analysis studied [4].

In the pink pigment lake, depicted in layer 3, Table 3, potassium and sulphur were identified by SEM-EDS analysis, which could be associated to the additives of the organic pigment. Calcium carbonate and gypsum in a mixed proteinaceous \& polysaccharide tempera were confirmed by infrared spectroscopy in a carmin motif in this book, Fig. 5c. This pink pigment lake was applied in backgrounds, clothes, flowers and line-fillers, as an opaque light pink or a translucent carmine. In these cases, the pink pigment was characterised by microspectrofluorimetry as a brazilwood lake, and a very good match was obtained with the historical reconstructions from recipes 9 and 27 from The book how to make colours [53]. The excitation $(560 \mathrm{~nm})$ and emission $(590 \mathrm{~nm})$ maxima correlate well with the excitation $(555 \mathrm{~nm})$ and emission (590-600 nm) maxima representative of brazilwood lake reconstructions, Fig. $5 \mathrm{~d}$.
In layer 4, silver is applied as a leaf with ca. $250 \mathrm{~nm}$ thickness, which may have lost thickness from the origin due to the formation of silver sulphide, Table 3. (see Additional file 1). SEM-EDS analysis show a greyish wrinkled surface, with the presence of $\mathrm{S}$ and $\mathrm{Ag}$, which indicates that the surface is degraded and possibly converted into silver sulphide $\left(\mathrm{Ag}_{2} \mathrm{~S}\right){ }^{1}$ The silver surface morphology shows a groove and filament pattern that may have resulted from the solubility of a precursor of silver sulphide (e.g., silver oxide).

Concerning the paint binder's distribution, SEM-EDS analysis in different layers, suggests that the two binders, polysaccharide and proteinaceous, may have been applied as mixture and not separately as binder and varnish.

\footnotetext{
1 When exposed to the excitation beam, the silver sulphide was converted into metallic silver and, with continuous irradiation, the silver surface disappears, leaving the layer beneath exposed. This is the reason why in the SEM images we see small white/bright points distributed over the oxidized grey layer.
} 


\section{Analysis by SEM-EDS of the silver grounds from the red} flower bud

The second case study was focused on the ground used to create the flower bud in folio 73 (microsamples B1 and B2). In Fig. 3, we reconstruct it, step by step. A silver leaf is applied over the ground; then, it is minium, the name of a medieval pigment is applied to depict the petals of the bud and malachite to depict the stem; finally, a pink pigment lake is applied in the final details and to outline the flower. Infrared spectrum shows that the ground is made of chalk, major compound, gypsum and a polysaccharide binder, Fig. 6a-c. Due to the severe silver degradation, it was difficult to conclude, by SEM-EDS analysis, if a thin layer of gypsum was applied over the chalk or if
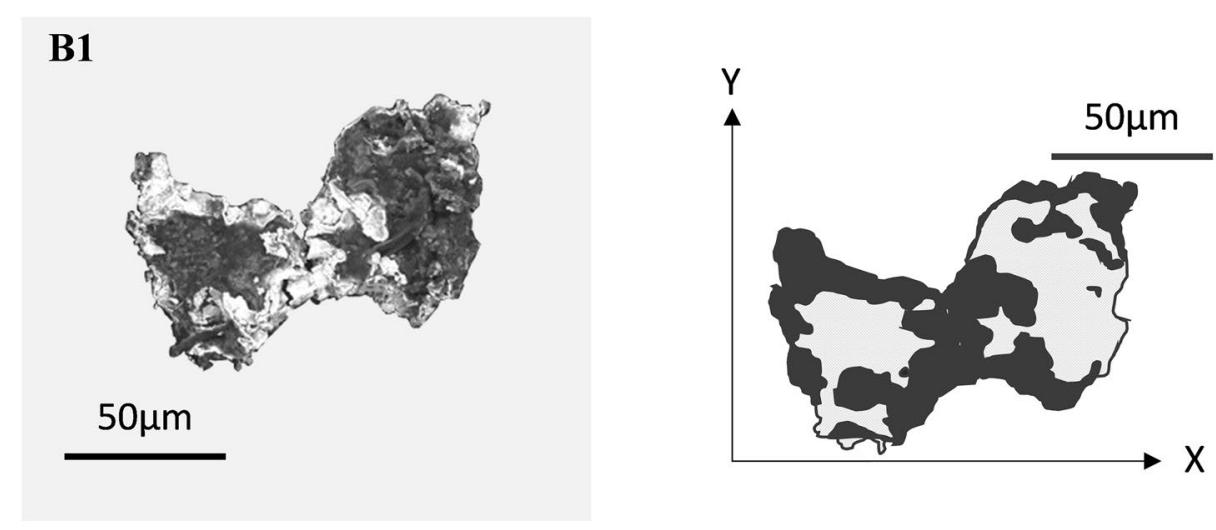

\section{B2}
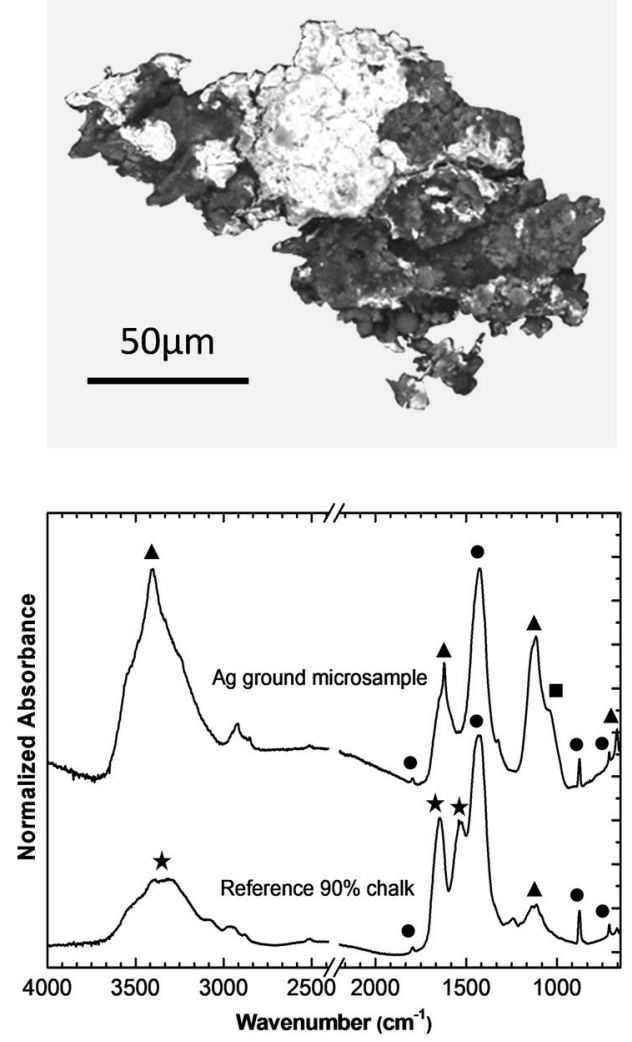
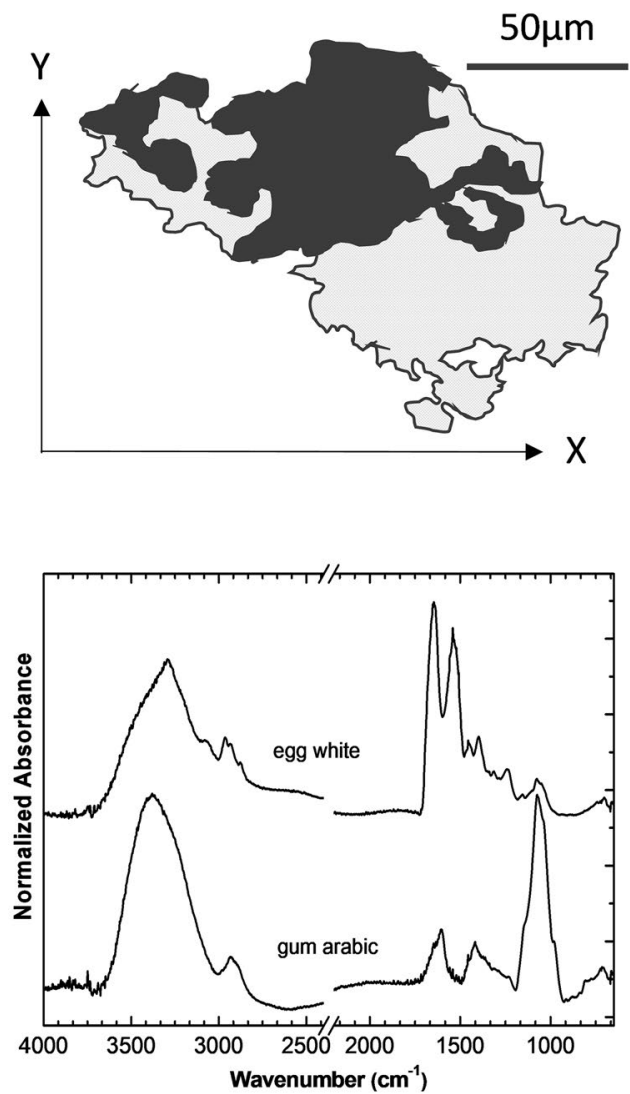

Fig. 6 SEM images of the microsamples (backgrounds were removed) from the red flower bud in folio 73: B1 and B2 and its schematic depiction: in black is silver and in gray is the ground composed by chalk and gypsum. Infrared spectra, bottom left, from the ground displaying chalk (filled circle), gypsum (filled triangle) and a polysaccharide binder (filled square) compared with a reference proteinaceous (filled star) paint: $90 \%$ chalk: $10 \%$ gypsum. Bottom right, egg white and gum arabic references 
they were applied as a mixture. To quantify the amount of chalk and gypsum present, mock-ups of both compounds in several ratios were prepared, ranging from 90:10 to 10:90, applied as collagen paints or prepared as $\mathrm{KBr}$ pellets. Based on the infrared analysis, we proposed that the ground is composed by circa $90 \%$ chalk and $10 \%$ gypsum, Fig. 6c. A more accurate quantification of the ground, concerning the SEM-EDS data, is in progress.

\section{Analysis in situ by $\mu$-EDXRF, $\mu$-Raman and optical microscopy of the silver paint in the window and blue flower}

The silver paints construction of the window on folio 25 and flower at the margin on folio 91, Fig. $7 \mathrm{a}-\mathrm{c}$, is based on XRF, Raman analysis and Leica KL 1500 LCD microscope observation.

In Fig. 3 we propose the stratigraphies for the different applications of silver paints found in Ms Cofre no31; based on a microscopic observation, we suggest that to create the effect of light in the window, silver leaf was applied over the parchment support without ground, as verified by the gaps of the metallic leaf; then, the cames of the window were constructed with a black pigment, which was not possible to identify by $\mu$-Raman, since indigo was applied over it, Figs. 3 and 7c.

For the flower of folio 91, Fig. 3, we propose that: firstly, gold was applied over the parchment support without ground, except in the centre of the flower; then, silver leaf was applied over the gold, leaving the centre of the flower discovered; and secondly, lapis lazuli was used to draw the petals of the flower outlines and then applied to shade the silver surface, Fig. $8 \mathrm{a}-\mathrm{c}$.

\section{Conclusions}

In this work, we proved that it is possible, using in situ examination (microscope) and analytical methods ( $\mu$-EDXRF and $\mu$-Raman) to disclose the complete stratigraphy of silver based paints in medieval illuminations. The case studies selected covered different typologies, ranging from silver applied directly on the parchment, over a gypsum and/or calcium carbonate ground or over paint layers; silver could be the final or the background layer over which pigments were applied. We also proved that our designed microsample preparation enabled a more accurate analysis and, consequently, a better understanding of the stratigraphy of the silver application.

In three of the four typologies studied, the silver leaf was severely degraded, having lost completely its metal brightness and appearing as a blackish fuzzy shape. SEM-EDS technique indicates that in the interface with air, $\mathrm{Ag}_{2} \mathrm{~S}$ is formed; it also proved that this surface looks lixiviated, possibly as a result of a soluble salt dissolution, which could not be $\mathrm{Ag}_{2} \mathrm{~S}$ (an extremely insoluble salt). a

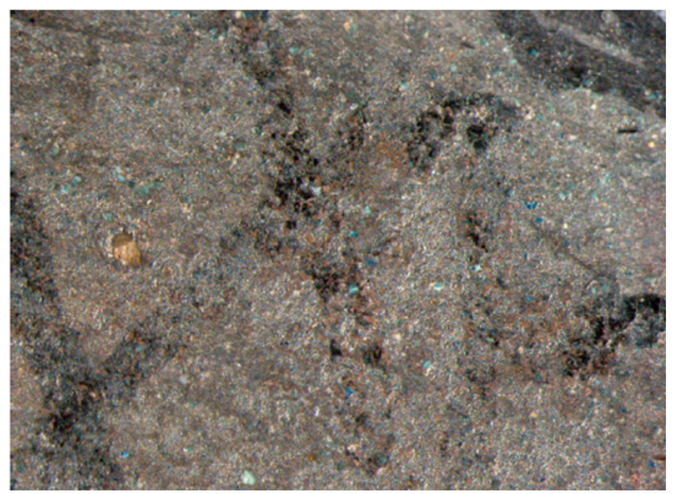

b

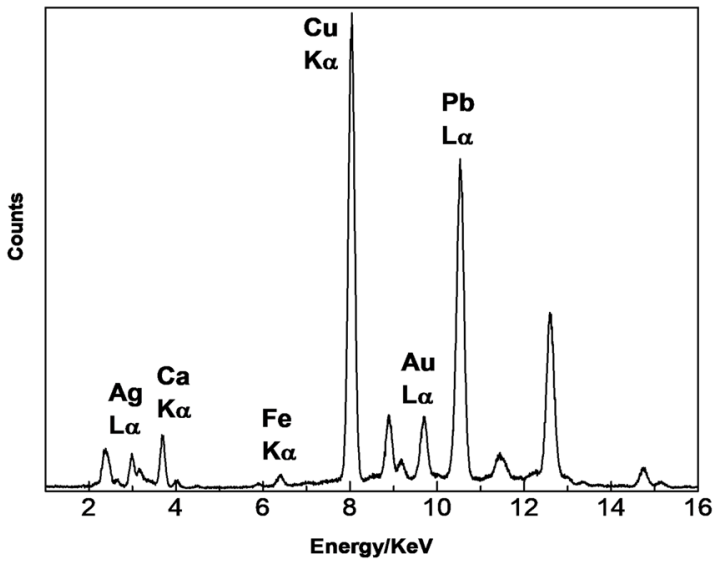

c

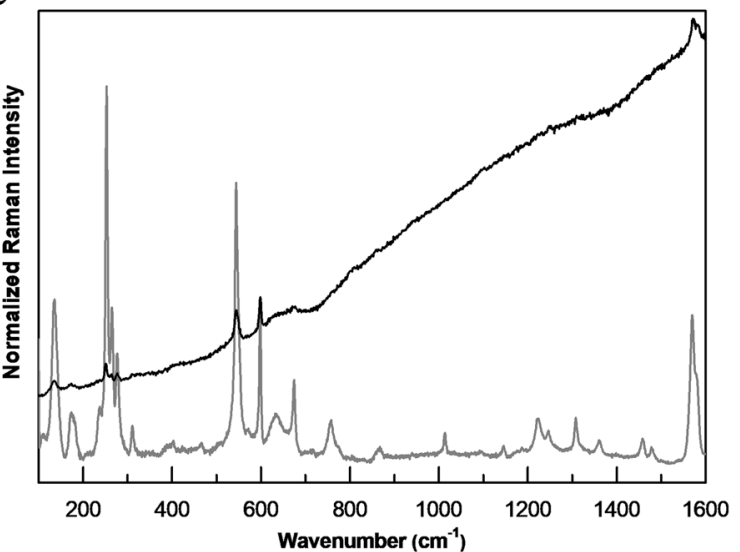

Fig. 7 a Detail of the window in folio 25. b XRF spectrum from the silver leaf applied on the window. $\mathbf{c}$ Raman spectrum from the blue colour applied as a glaze over the silver (black line) and an indigo reference (gray line)

Knowing from literature that the first intermediate corrosion compound is $\mathrm{Ag}_{2} \mathrm{O}$ [41], it is possible that this intermediate, before being converted into $\mathrm{Ag}_{2} \mathrm{~S}$, may spread over the surface. Thus, the blackish colour occupies the larger area with the fuzzy contour described above. 
It was also proved that the degradation products may only be detected in microsamples, both by Raman microscopy and with SEM-EDS analysis. Sample preparation was extremely challenging due to their very small size, circa of $100 \mu \mathrm{m}$. Best results were obtained with SEM-EDS, namely when the microsample was embedded in an acrylic resin, Fig. 4. However, it was not possible to study the degradation products formed at the several layer interfaces and consequently to assess the pigment/binder effects on silver degradation since oxidized forms of silver were converted into metallic silver under the beam exposure. Thus, it was not possible to acquire the signal for longer times and in small areas. We could also observe sublimation of metallic silver or/and of the products formed by the beam. So, other analytical techniques with the high spatial resolution provided by SEM, or higher, must be envisaged to study the degradation mechanism of silver based paints, concerning the interface layers, in medieval illuminations. Synchrotron based techniques will be considered for future work as has been carried out by Salvadós team [54, 55]. Knowing that, it is possible that in the literature it was possible to detect silver degradation compounds in ageing studies [56], we will further pursue studies based on Raman microscopy.

On the other hand, we could observe that the only silver paint in good conservation condition was the one applied to create the effect of light in a glass window, in which no ground was used and in which the overpaints are reduced to the draw of the cames and indigo applied over it as a glaze. Based on these preliminary results, in the future, we believe it will be important to discuss the effect of the ground on silver degradation, by analysing the influence of binders and pigments individually on model systems.

We consider that one of the major contributions of this work is that it shows that the simple model depicted in Eq. 1 for silver oxidation does not allow to understand the complex phenomena that intervene in silver paints degradation in medieval illuminations. It is important to bear in mind that the first reactive intermediate to be formed is the silver oxide, a relative soluble compound when compared with silver sulphide, this latter is the ultimate degradation product.

This also impacts how we envisage the effect of silver degradation in the other paint colours. Importantly,

$\mathbf{a}$

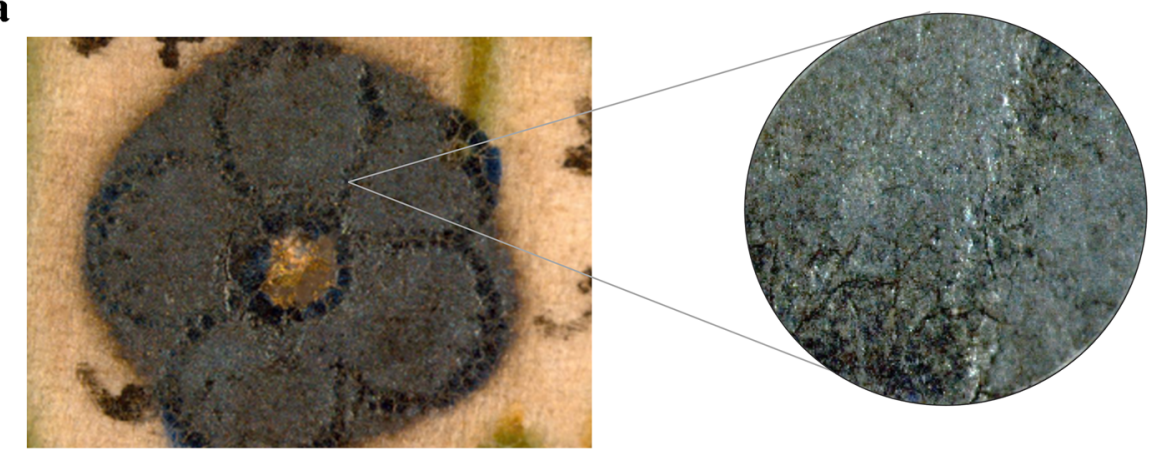

b

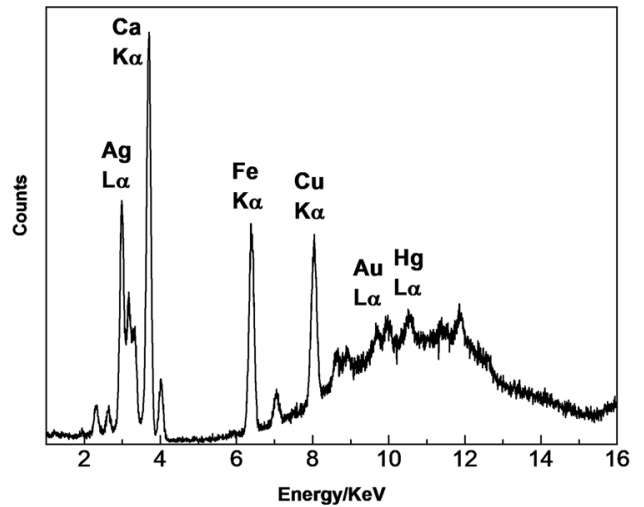

c

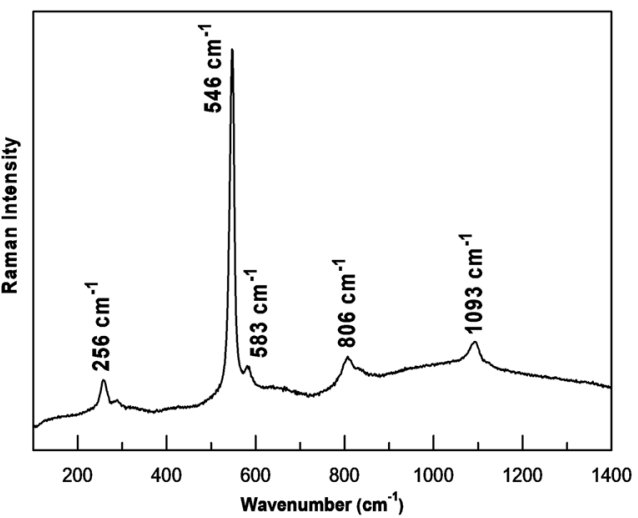

Fig. 8 a Detail of the flower in folio 91 and highlight of the blue outline. b XRF spectrum from the silver leaf. c Raman spectrum of the lapis lazuli outline 
the use of SEM-EDS technique allows proposing that the spreading of the black corrosion product is a consequence of lixiviation of soluble intermediates formed during silver oxidation, Table 3, layer 4.

Considering silver sulphide $\left(\mathrm{Ag}_{2} \mathrm{~S}\right)$ is formed at the expenses of silver oxide $\left(\mathrm{Ag}_{2} \mathrm{O}\right)$, in an environment in which $\mathrm{S}^{2-}$ species are present, it is understandable how the binding of the book can minimize the entry of humidity and air pollutants into the textblock, thus constituting a primordial and essential line of defence. This is also in accordance with the first results of the conservation survey that is being done on the books of hours kept in Portuguese institutions, where was observed that the books keeping early bindings are the ones where illumination, namely silver paint, reveals less degradation.

The information collected and critically analysed in this work will contribute to a better understanding of the silver application and will prepare the ground for the development of methods for the stabilization and conservation of these illuminations.

\section{Additional file}

Additional file 1. SEM image with the thickness of the silver leaf.

\section{Authors' contributions}

RA: acquisition, preparation, analysis and interpretation of data; contributing to the degradation mechanism of silver leaf; writing the article. MJM: conception and design of the research work; acquisition and preparation of microsamples and interpretation of data; contributing to the degradation mechanism of silver leaf; drafting and reviewing the article and final approval of the version to be published. PN: acquisition, analysis and interpretation of data; contributing to the degradation mechanism of silver leaf. IPC: acquisition and preparation of microsample; contributing to the writing of the version to be published. CC: contributing to the writing and revision of the version to be published. AL: contributing to the writing and revision of the version to be published concerning the art historical study of cofre no31. All authors read and approved the final manuscript.

\section{Author details}

${ }^{1}$ DCR and LAQV-REQUIMTE, Faculty of Sciences and Technology, Universidade NOVA de Lisboa, Campus da Caparica, 2829-516 Caparica, Portugal. ${ }^{2}$ IEM, Faculty of Social Sciences and Humanities, Universidade NOVA de Lisboa, Avenida de Berna 26-C, 1069-061 Lisbon, Portugal.

\section{Acknowledgements}

The authors would like to thank the support and collaboration of the directors and staff from Mafra National Palace and António Jorge Parola, Fernando Pina and Sara Fragoso by the helpful and exciting discussions on silver degradation mechanisms.

\section{Competing interests}

The authors declare that they have no competing interests.

\section{Availability of data and materials}

Not applicable.

Ethics approval and consent to participate

Not applicable.

\section{Funding}

This study was supported by the Portuguese Science Foundation through the CORES Ph.D. Doctoral Programme in the Conservation and Restoration of Cultural Heritage with the Grants [SFRH/BD/52314/2013] and [PD/ BD/105895/2014] and by Associated Laboratory for Sustainable ChemistryClean Processes and Technologies-LAQV which is financed by national funds from FCT/MEC (UID/QUI/50006/2016) and co-financed by the ERDF under the PT2020 Partnership Agreement (POCI-01-0145-FEDER-007265).

\section{Publisher's Note}

Springer Nature remains neutral with regard to jurisdictional claims in published maps and institutional affiliations.

Received: 6 November 2017 Accepted: 4 February 2018

Published online: 13 March 2018

\section{References}

1. Melo MJ, Castro R, Miranda A. Colour in medieval Portuguese manuscripts: between beauty and meaning. In: Sgamellotti A, Brunetti B,

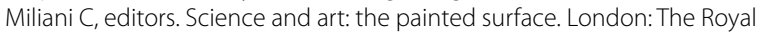
Society of Chemistry; 2014. p. 170-92.

2. Melo MJ, Araújo R, Muralha VSF, Lemos A. O que nos dizem os materiais da cor sobre os Livros de Horas do Palácio Nacional de Mafra? In: Lemos A, editor. Catálogo dos Livros de Horas do Palácio Nacional de Mafra. Lisboa: Instituto de Estudos Medievais da FCSH-UNL/Palácio Nacional de Mafra; 2012. p. 95-107.

3. Lemos A, Araújo R, Casanova C, Melo MJ, Muralha VSF. Regards croisés des historiens de l'art et des chimistes sur deux livres d'Heures de la Bibliothèque nationale du Portugal, les mss IL15 et IL19. In: Miranda MA, Miguélez A, editors. Portuguese studies on medieval illuminated manuscripts. Madrid-Barcelona: Brepols; 2014. p. 145-68; isbn: 978-2-503-55473-0.

4. Melo MJ, Otero V, Vitorino T, Araújo R, Muralha VSF, Lemos A, Picollo M. A spectroscopic study of brazilwood paints in medieval books of hours. Appl Spectrosc. 2014;68:434-44. https://doi.org/10.1366/13-07253.

5. Araújo R, Casanova C, Melo MJ, Lemos A. Ethical and technical concerns during the conservation process of a religious book, the book of hours from the library of Palácio Nacional de Mafra. Eur J Sci Theol. 2015;11:129-40.

6. Lemos A, Araújo R, Casanova C. O Cofre no 24: um livro de horas do Palácio Nacional de Mafra, caso de estudo. Invenire. Revista de Bens Culturais da Igreja_Fiat Lux: Estudos sobre manuscritos iluminados em Portugal. Especial. 2015;82-93; issn: 1647-8487.

7. Melo MJ, Araújo R, Castro R. Colour degradation in medieval manuscripts. Microchem J. 2016;124:837-44. https://doi.org/10.1016/j.micro c.2015.10.014.

8. Melo MJ, Araújo R, Casanova C, Muralha V, Lemos A. Segredos descobertas nos Livros de Horas: história, materiais e técnicas. In: Custódio D, Miranda MA, editors. Livros de Horas: o imaginário da devoção privada. Lisbon: Instituto de Estudos Medievais/Biblioteca Nacional de Portugal; 2015. p. 193-225; isbn: 9789725655627.

9. Araújo R, Casanova C, Lemos A. Estudo das encadernações de dois livros de horas da BNP: o IL 15. In: Barreira CF, editor. Luz, cor e ouro. Estudos sobre manuscritos iluminados. Lisbon: Biblioteca Nacional de Portugal. 2016. p. 201-13. Lisbon: 978-972-565-600-6.

10. Araújo R. Examining the books of hours in Portuguese collections. In: Golob N, Vodopivec J, editors. Bookbindings: theoretical approaches and practical solutions. Turnhout: Brepols Publishers; isbn: 978-2-503-57498-1. Forthcoming 2017.

11. Araújo R. Os livros de horas (séc. xv) na coleção do Palácio Nacional de Mafra: estudo e conservação (master dissertation). Caparica: Faculty of Sciences and Technology, New University of Lisbon; 2012. http://run.unl. pt/bitstream/10362/9329/1/Araujo_2012.pdf.

12. Carvalho, I. Processos de degradação em manuscritos iluminados: estudo, conservação e restauro de um livro de horas do século XV do Palácio Nacional de Mafra (master dissertation). Caparica: Faculty of Sciences 
and Technology, New University of Lisbon; 2015. https://run.unl.pt/bitst ream/10362/17113/1/Carvalho_2015.pdf.

13. Muñoz SV. The technical analysis of Renaissance illuminated manuscripts from the Historical Library of the University of Valencia/Estudio técnico de los códices miniados renacentistas de la Biblioteca Histórica de la Universidad de Valencia. Cambridge: Straus Center for Conservation and Technical Studies, Harvard University Art Museums; Valencia: Universidad Politécnica de Valencia; 1999.

14. Oltrogge D. Byzantine recipes and book illumination. Rev Hist Arte. 2011;1:59-71.

15. Clarke M. The analysis of medieval European manuscripts. Rev Conserv. 2001;2:3-17. https://doi.org/10.1179/sic.2001.46.

16. Watteeuw $L, B o s ~ M ~ V a n$. The conservation assessment of an illuminated Book of Hours. Understanding craftsmanship through interdisciplinary research: preliminary investigation. In: Bridgland J, editor. Diversity in heritage conservation: tradition, innovation and participation: ICOM committee for conservation, 15th triennial conference, New Delhi; 2008; p. 310-16.

17. Turner N. The conservation of medieval manuscript illuminations and the question of compensation. Waac Newslett. 1994;16:21-2.

18. Bos M Van, Watteeuw L. Analysis of the Anjou Bible. Medieval Colours, Revista de História da Arte, FCSH-UNL, no 1, série W 2011. p. 194-204 https://revistadehistoriadaarte.files.wordpress.com/2011/09/art14.pdf.

19. Watteeuw L. Flemish manuscript production, care, and repair: fifteenth century sources. In: Morrison E, Kren T, editors. Flemish Manuscript Painting in Context: recent research. Los Angeles: Getty Publications; 2006. p. 73-86; isbn: 0-89236-852-7.

20. Guineau B, Villela-Petit I, Akrich R, Vezin J. Painting techniques in the Boucicaut Hours and in Jacques Coene's colour recipes as found in Jean Lebègue's Libri Colorum. In: Roy A, Smith P, editors. Painting techniques history, materials and studio practice: contributions to the 1998 IIC Congress; 1998 September 7-11; Dublin. London: International Institute for Conservation of Historic and Artistic Works; 1998. p. 51-4.

21. Lawson M, Yamazaki-Kleps A. Examination and conservation of the fifteenth-century parchment manuscript, the Belles Heures of Jean, Duke of Berry. In: Daniels V, Donnithorne A, Smith P, editors. Works of art on paper, books, documents and photographs: techniques and conservation: contributions to the 2002 Baltimore Congress: works of art on paper; 2002 September 2-6; Baltimore. London: International Institute for the Conservation of Historic and Artistic Works; 2002. p. 129-34

22. Thomas K. Looking at Louis XII's Bathsheba. In: Kren T, Evans M, editors. A masterpiece reconstructed: the hours of Louis XII. Los Angeles: Getty Publications; 2005. p. 43-61.

23. Turner N. The manuscript painting techniques of Jean Bourdichon. In: Kren T, Evans M, editors. A masterpiece reconstructed: the hours of Louis XII. Los Angeles: Getty Publications; 2005. p. 63-79.

24. Nastova I, Grupce O, Minceva-Sukarova B, Ozcatal M, Mojsoska L. Spectroscopic analysis of pigments and inks in manuscripts: I. Byzantine and post-Byzantine manuscripts (10-18th century). Vib Spectrosc. 2013;68:11-9.

25. Guerra M, Manso M, Pessanha S, Le Gac A, Longelin S, Guilherme A, Gil M, Seruya Al, Carvalho ML. X-ray fluorescence spectrometry as a diagnostic tool in characterization and conservation of manueline-illuminated manuscripts. In: Fediani P, Frediani M, Rosi L, editors. Cultural heritage: protection, developments and international perspectives, chapter 9. New York: Nova Science Publishers; 2013. isbn: 978-1-62808-822-9.

26. Costa V. The deterioration of silver alloys and some aspects of their conservation. Rev Conserv. 2001;2:18-34.

27. Portell JD. Colored glazes on silver — gilded surfaces. Stud Conserv. 1992;37:116-8.

28. Guerra MF, Tissot I. The role of nuclear microprobe in the study of technology, provenance and corrosion of cultural heritage: the case of gold and silver items. Nucl Instrum Methods Phys Res B. 2013;306:227-31.

29. Tronner K, Nord AG, Sjostedt J, Hydman H. Extremely thin gold layers on gilded silver threads. Stud Conserv. 2002;47:109-16.

30. van Langh $\mathrm{R}$, Ankersmit HA, Joosten I. The delamination of silversulphide layers. In: Proceedings of metal. 2004. p. 137-41.

31. Salvadó N, Butí S, Labrador A, Cinque G, Emerich H, Pradell T. SR-XRD and SR-FTIR study of the alteration of silver foils in medieval paintings. Anal Bioanal Chem. 2011;399:3041-52.
32. Sease C, Selwyn LS, Zubiate S, Bowers DF, Atkins DR. Problems with coated silver: whisker formation and possible filiform corrosion. Stud Conserv. 1997:42(1):1-10

33. Turovets I, Maggen M, Lewis A. Cleaning of daguerreotypes with an excimer laser. Stud Conserv. 1998;43(2):89-100.

34. Barger MS, Giri AP, White WB, Edmondson TM. Cleaning daguerreotypes. Stud Conserv. 1986:31(1):15-28.

35. Daniels V. Plasma reduction of silver tarnish on daguerreotypes. Stud Conserv. 1981:26:45-9.

36. Frey T, Kögel M. Tarnish protection of silver jewels by plasmapolymer coatings. Surf Coat Technol. 2003;174-175:902-4. https://doi. org/10.1016/S0257-8972(03)00713-8.

37. Reiche I, Berger A, Görner W, Merchel S, Riederer J, Riesemeier H, Roth M. Following the traces of Albrecht Dürer: analysis of silverpoint drawings by spatially resolved synchrotron-induced X-ray fluorescence analysis. Nucl Instrum Methods Phys Res B. 2004;226(1-2):83-91.

38. Radepont M, Bonnot-Diconne C, Thao S, Pacheco C, Bouttemy M, Delbos E. Impacts of manufacturing and conservation on the silver leaf tarnishing in gilt leather. In: ICOM-CC 18th triennial conference Copenhagen. 2017.

39. Homem P. Corrosão atmosférica da prata: monitorização e perspectivas de conservação preventiva (PhD thesis). Oporto: Faculdade de Letras da Universidade do Porto; 2013.

40. Capelo S, Homem PM, Cavalheiro J. Linear sweep voltammetry: a cheap and powerful technique for the identification of the silver tarnish layer constituents. J Solid State Electrochem. 2013;17:223-34.

41. Besenbacher F, Nørskov JK. Oxygen chemisorption on metal surfaces: general trends for Cu, Ni and Ag. Prog Surf Sci. 1993;44:5-66.

42. Leygraf C, Graedel T. Atmospheric corrosion. New York: Wiley; 2016.

43. Dean JA. Lange's handbook of chemistry. New York: McGraw-Hill; 1999.

44. Whitley KP. The gilded page: the history \& technique of manuscript gilding. New Castle: Oak Knoll Press and The British Library; 2010.

45. Smith CS, Hawthorne JG. Mappae Clavicula: a little key to the world of medieval techniques. Trans Am Philos Soc. 1917;64(4):1-128.

46. Hawthorne JG, Smith C. Theophilus. On divers arts. New York: Dover; 1963.

47. De Brunello F. Arte Illuminandi e altri trattati sulla miniatura medieval. Vicenza: Neri Pozza Editore; 1992.

48. Clarke M. Mediaeval painters' materials and techniques. London: Archetype Publications; 2011.

49. Strolovitch DL. Old Portuguese in Hebrew script: beyond O libro de como se fazem as cores. In: Afonso LU, editor. As Matérias da Imagem. Lisbon: Cátedra de Estudos Sefarditas «Alberto Benveniste» da Universidade de Lisboa; 2010. p. 29-43.

50. Thompson DV. The Craftsman's Handbook'll libro dell'Arte' by Cennino d'A Cennini. New York: Dover Publications; 1954.

51. Merrifield MP. Medieval and renaissance treatises on the arts of painting. London: Dover Publications; 1999.

52. Barreira C, Melo MJ, Araújo R, Casanova C. Through the eyes of science and art: a fourteenth-century winter breviary from Alcobaça scriptorium. J Mediev Iber Stud. 2016;8(2):252-82.

53. Vitorino T, Melo MJ, Carlyle L, Otero V. New insights into brazilwood manufacture through the use of historically accurate reconstructions. Stud Conserv. 2016;61:255-73. https://doi.org/10.1179/2047058415 Y.0000000006.

54. Salvadó N, Butí S, Pradell T, Cinque G. Silver alterations in medieval altarpieces: combined X-ray and IR microanalysis by synchrotron radiation. Diamond Light Source Annual Report. 2011. p. 23-4.

55. Salvadó N, Butí S, Clemente C, Beltran V, Cinque G, Juanhuix J, Pradell T. Microanalytical study of luster glazed gilding and silvering from Baroque altarpieces. Pure Appl Chem. 2017. https://doi.org/10.1515/ pac-2017-0602.

56. Martina I, Wiesinger R, Jembrih-Simburger D, Schreiner M. Micro-Raman characterization of silver corrosion products: instrumental set up and reference database. E-Preserv Sci. 2012;9:1-8. 